\title{
Characterization of Old Apple Cultivars from Bosnia and Herzegovina by Means of Pomological and Biochemical Analysis
}

\author{
Sanda STANIVUKOVIĆ ${ }^{1 *}$, Milan ŽUJIĆ², Mirjana ŽABIĆ², \\ Nikola MIĆIĆ ${ }^{2}$, Borut BOSANČIĆ ${ }^{2}$, Gordana ĐURIĆ ${ }^{1}$ \\ ${ }^{1}$ University of Banja Luka, Genetic Resources Institute, Bulevar vojvode Petra Bojovića Ia, Banja Luka, Bosnia and Herzegovina; \\ sanda.stanivukovic@griunibl.rs.ba(*correspondingauthor);gordana.djuric@griunibl.rs.ba \\ ${ }^{2}$ University of Banja Luka, Faculty of Agriculture, Bulevar vojvode Petra Bojovića 1a, Banja Luka, Bosnia and Herzegovina; mzujic@yahoo.o ; \\ mirjana.zabic@agrofabl.org;nikola.micic@agrofabl.org;borut.bosancic@agrofabl.org
}

\begin{abstract}
The assessment of quality of old apple varieties was made in order to preserve and use these germplasm in the area of Bosnia and Herzegovina. The characterization was done for ten old varieties of apples selected on the basis of good characteristics of sensory analysis. The following parameters were considered: fruit weight, fruit length and width, stalk length and width, fruit flesh firmness; soluble solids content and total dry matter content of the fruit juice; $\mathrm{pH}$, titratable acidity (TA), vitamin C, total phenolics, total flavonoids and antioxidant potential evaluated by DPPH radical scavenging assay. Statistical analysis was performed separately for sensory, pomological and biochemical characterization (in two consecutive years) by analysis of variance. Only traits such as weight, width and height of the fruit were the biggest in 'Vinjugara' which had a low content of titratable acidity whereby it could be singled out as an acceptable variety for consumers. 'Đedovača' had the highest content of phenols (1711.8 mg GAE/100 g of fruit weight), which is in complete relationship with good free radical scavenging activity (11.1 mg of fresh fruit/ml). 'Kolačara' and 'Gospoinjača' were distinguished as particularly interesting for good nutritional characteristics, primarily the content of phenols, flavonoids and free radical scavenging ability, but also for suitable storage characteristics, ${ }^{\circ}$ Brix content and firmness. Due to favourable pomological and biochemical characteristics these varieties were recommended to be included in the breeding program that will result in the enrichment of germplasm of the apples from these areas.
\end{abstract}

Keywords: Malus $\times$ domestica Borkh, biodiversity, fruit quality, pomology, biochemical characterization

\section{Introduction}

The current climate changes, as well as the possibility of appearance of new pests, represent a real threat to the survival and profitability of commercial production of fruits. Local and old varieties are generally suppressed from production although their value in terms of biodiversity is extremely high (Đurić et al., 2014). Over the past thirty years, attention has been devoted to the collection, conservation and evaluation of apple diversity, with two main purposes: to conserve a wide genetic variability for breeding programs and to extend the exploitation of old varieties in organic or integrated fruit production (Kellerhals et al., 2004). Local and old varieties, as opposed to commercial varieties, often carry specific and uncommon properties that are interesting to a smaller number of consumers. Therefore, in order for these varieties to return to small production (niche markets), it is important that consumers understand the kind of properties that distinguish them from standard varieties on the market (Mitre et al., 2009; Dan et al., 2015). Re-introduction of these varieties into production, i.e. sustainable usage, represents the best way to preserve this germplasm for future generations (Bignami et al., 2003). A selection of varieties for re-cultivation, is dependent on their properties (taste, color, firmness, ripening time, suitability for storing), which is why it is extremely important for these varieties to be evaluated. Because of all this, the work on conservation and characterization of old and local varieties is intense in most countries and institutes (Mratinić and Fortirić Akšić, 2011). Bosnia and Herzegovina is extremely rich in fruit germplasm (Paunović et al., 1997; Đurić et al., 2009; Gaši et al., 2010), as an area which has been exposed to migrations and the influence of different cultures for cenruries. The mixing of influences of the East and the West and the introduction of new germplasm from different areas is particularly evident in the area of $\mathrm{BiH}$ (Đurić $e t$ al. 2009). In such a richness of fruit plants, a lot of old varieties of apples have survived (Beširević, 2009; Đurić et al., 2009; Gaši et al. 2010), although an organized collection work and evaluation of this germplasm does not go far back into the past. As a result of this work, only a few collections of apples were created, including the most important ones in Srebrenik and Banja Luka. In the collection in Srebrenik, which was built in 2000, there are 60 new accessions of apple (Gaši et al., 2010), whereas in the collection of Banja Luka, which was built in 2013, there are 84 old, local and/or 
domesticated varieties of apples (Đurić et al., 2016). A small number of varieties of these two collections were given the same name. The varieties of collections from Srebrenik were the subject of morphological and genetic (Gaši et al., 2010) as well as pomological characterization (Kecman, 2015) whereas the varieties of apples from the collection in Banja Luka have not been fully evaluated yet. In recent years, more attention has been paid to the nutritional value of fruits, i.e. the vitamin $\mathrm{C}$ content and antioxidant activity. Nutritional value of fruit is becoming more popular in terms of its impact on the health status of consumers (Lutaladio et al., 2010). Great importance is given especially to apples as fruit species which might, in the future, play an important role in preventing various diseases, but also in neutralizing free radicals and preventing the aging of cells (Delian et al., 2011). The trees of old apple varieties, which mainly grow without special agricultural technology, and adapt well to changing environmental conditions (Selamovska, 2014), are expected to have substantially higher content of phenols and flavonoids whose production is a result of plant response to their greater exposure to environmental stress. There is already plenty of evidence that these secondary metabolites have a beneficial effect on health, mostly because of their ability to capture harmful free radicals, which is why phenols and flavonoids have strong antioxidant and antimicrobial activity (Milenković, 2013). Their antioxidant activity is reflected in neutralizing free radicals (Percival, 1998) and they also have a very important physiological and morphological role in the growth and reproduction of plants and contribute to the color and sensory characteristics of fruits. The content of these compounds depends on the species, but also on the variety within the same species (Đurić et al., 2015). In addition to these, for the selection of varieties as genetic material for breeding purposes, significant are also some other properties of the fruit: fruit flesh firmness, soluble solids content, total dry matter content, acidity of the cell juice, the content of total organic acids and vitamin C content (Mratinić and Fortirić Akšić, 2012). The texture characteristics, mechanical and elastic properties respectively sensory characteristics (taste, aroma, crunchiness) are some of the more important indicators of the quality of apples (Corollaro et al., 2013) but are also decisive factors from the consumers' standpoint $(\mathrm{Lu}, 2004)$.

\section{Materials and Methods}

\section{Location and plant material}

Based on preliminary sensory analysis, ten apple cultivars ('Vidovka Crvena,', 'Vidovka Žuta', 'Petrovača', 'Crvena Petrovka', 'Đedovača', 'Gospoinjačá,' 'Vinjugara', 'Kolačara', ‘Šipunja'and 'Šarenika'), collected from the area of north-western Bosnia and Herzegovina, were selected for detailed pomological and biochemical fruit analysis. The fruits were taken in the period of full maturity, from the previously marked trees. Ten fruits were randomly sampled of each accession/variety, on which the first pomological characterization was performed and, after that, the samples were homogenized in a blender and stored at $-20{ }^{\circ} \mathrm{C}$ before biochemical analyses were performed in triplicate. Graft branches were taken from the same trees for the production of seedlings to include into the collection of fruit trees of the Genetic Resources Institute of the University of Banja Luka. These varieties have not been previously analyzed (not included in the collection orchard in Srebrenik). Only 'Crvena Petrovka' accession indicates, by its name, a similarity with the accession 'Petrovača Crvena' from the collection in Srebrenik.

\section{Determination of sensory parameters}

In sensory characterization of new accessions, customers / consumers of different age and gender evaluated the following characteristics of fruit: shape, colour, crunchiness, firmness, initial juiciness, prolonged juiciness, sweetness, acidity and mealiness of the fruit. Ratings were expressed numerically on a scale of 1 to 7 , where varieties were tested according to certain sensory properties and allocated as interesting for further analysis.

\section{Determination of pomological parameters}

Fruit weight was determined by weighing on a digital scale KERN EMB (KERN \& Sohn Gmbh, Germany) with a measuring range of $0-600 \pm 0.01 \mathrm{~g}$. Length and width of the fruit and stalks was carried out by a digital caliper (Unior, No 270), with measuring range of $0-150 \mathrm{~mm}$. The firmness of the fruit $\left(\mathrm{kg} \mathrm{cm}^{-2}\right)$ was is determined by penetrometer FT 327 (Fruit Pressure Tester, Italy) stem diameter $11 \mathrm{~mm}$ by Đurić et al. (2015).

\section{Determination of biochemicalparameters}

Freshly squeezed and filtered juice of each fruit was used for determination of soluble solid content using a refractometer ATAGO (Atago, CO., LTD., Japan) operating range $0-32^{\circ}$ Brix. The measurement of $\mathrm{pH}$ was done by immersing the electrode of a standardized $\mathrm{pH}$ meter (Hanna $\mathrm{pH}$ 211, Hanna Instruments, Cluj, Romania) in a homogenized sample at room temperature. Titratable acidity (TA) was determined by titration with a solution of $0.1 \mathrm{M} \mathrm{NaOH}$ to $\mathrm{pH} 8.1$, and expressed as \% of the malic acid (Đurić et al., 2015). Preparation of fruit extracts for determination of total phenols and total flavonoids was performed according to the method described by Tehrani et al. (2011). Total phenols content was determined by Folin-Ciocalteu (FC) colorimetric method (Singleton and Rosi, 1965) and the results were expressed as $\mathrm{mg}$ of gallic acid equivalents (GAE) per $100 \mathrm{~g}$ fresh weight. The content of total flavonoids was determined by the colorimetric method with aluminium chloride described by Tehrani et al. (2011) and the results were expressed as mg catechin equivalents (CE) per $100 \mathrm{~g}$ fresh weight. Sample preparation and free radical scavenging ability determination by quenching stable free 2,2-diphenyl-1-picrylhydrazyl (DPPH) radicals were performed according to Đurić $e t$ al. (2015), and the antioxidant was expressed as effective concentration (EC50), i.e. concentration at which $50 \%$ of DPPH radicals were quenched. Vitamin C content was determined by a standard AOAC (1990) 2,6dichlorophenolindophenol method. The dry matter content was determined by a standard AOAC (1990) method, by drying at a temperature of $105^{\circ} \mathrm{C}$ to constant weight.

\section{Statistical analysis}

The features of surveyed indigenous apple varieties were analyzed using analysis of variance. Pomological and biochemical properties were analyzed separately. For those properties found with significant statistical differences between varieties, further testing and grouping was established by Tukey's test. The total effect of a combination of different traits measured in the tested indigenous varieties of apples analyzed by the method of principal component analysis (Sneath and Sokal, 1973; Williams, 1976; Iezzoni and Pritts, 1991; Peres et al., 2003) by which the classification of the tested varieties was done. Statistical analysis and graphical presentation of results of statistical analysis were performed in the programs SPSS Statistics 22 (2013), and R (R Core Team, 2015). 


\section{Results and Discussion}

\section{Sensory characteristics}

The results of sensory analysis were used to select an assortment for pomological and biochemical characterization whereby the tested cultivars distinguished them by the shape and color of the fruit, the initial juiciness, prolonged juiciness, sweetness of fruit, acidity and mealiness of the fruit (Table 1).

Good coloration (6.71) and initial juiciness (5.43) singled 'Petrovka Crvena' out. 'Vinjugara' is also distinguished by good initial juiciness of the fruit (5.71) while 'Vidovka Crvena' maintained good juiciness of the fruit (5.71). The sweetness of the fruit flesh was statistically significantly earmarked with 'Petrovka Crvena' (5.71). As for the acidity of the fruit, interesting was 'Šarenika' (6.00). Fruits of 'Kolačara' were evaluated as having the highest mealiness (4.86), while 'Đedovača' was evaluated as the least mealy (1.43).

The principal components analysis (Fig. 1) singled out the two principal components cumulatively covering $70.49 \%$ of the variations.

The principal component 1 (42.58\% variations) covered the highest impacts of sweetness, shape and prolonged juiciness of the fruit in positive direction, and the firmness of the fruit in the opposite direction. The principal component 2 (27.91\% variations) was mostly comprised of variation under the influence of crunchiness, juiciness and the initial acidity of the fruit in a positive direction, and mealiness of flesh of the fruit in negative direction. The tested indigenous cultivars were grouped into two groups according to the analyzed sensory characteristics of the fruit. The first group consisting of 'Šarenika', 'Šipunja', 'Vinjugara' and 'Gospoinjača' was characterized by a noticeable acidity and crunchiness of the fruit. The second group comprised 'Petrovača', 'Vidovka Žuta', 'Vidovka Crvena' and 'Kolačara' with increased mealiness of the fruit, less crunchiness and greater flesh sweetness of the fruit. Special distinction singled out 'Petrovka Crvena' for good color and juiciness, greater sweetness and softness of the fruit and moderate acidity. 'Đedovača' on the other hand, was especially featured by its poorly evaluated shape and color of the fruit, reduced crunchiness and firmness of the fruit, and low mealiness of the fruit.

\section{Pomological characteristics}

Indigenous apple cultivars significantly differed in all measured pomological characteristics, $\mathrm{p}<0.001$ (Table 2 ).

The highest average fruit weight is allocated to 'Vinjugara' $(208,97 \mathrm{~g})$ and the lowest to 'Petrovača' (63.77 g). As for the firmness of the fruit, 'Kolačara' was singled out with $(11.38 \mathrm{~kg}$ $\mathrm{cm}^{-2}$ ), while the lowest firmness of the fruit cultivar was allocated to 'Petrovača' ( $4.91 \mathrm{~kg} \mathrm{~cm}^{-2}$ ) along with 'Crvena Petrovka' ( $5.21 \mathrm{~kg}$ $\mathrm{cm}^{-2}$ ). As for soluble solids content 'Gospoinjača' was dominated (15.78 'Brix), while both 'Vidovka Crvena' and 'Vidovka Žuta' showed minor content of soluble solids content compared to other cultivars tested. The height and width of the fruit particularly singled out 'Vinjugara' with very large fruits, while 'Petrovača' and 'Đedovača' had small fruits. 'Kolačara' was also singled out with extremely flattened fruit, i.e. with the widest fruit on one hand, while it was grouped together with the cultivars that were characterised by the extremely low height of the fruit on the other hand. As for the dimensions of the stalk 'Kolačara' was again particularly interesting having the shortest and the thickest stalk. On the other hand, 'Sarenika' was distinguished by a significantly long and thin stalk.

Table 1. Mean values $(\mathrm{x})$ and standard errors $( \pm)\left(s_{\mathrm{x}}\right)$ of the sensory characteristics of the studied autochthonous apple cultivars in Bosnia and Herzegovina

\begin{tabular}{|c|c|c|c|c|c|c|c|c|c|c|c|c|c|c|c|c|c|c|}
\hline Cultivar & & & Fruit & lour & & & Fruit & hness & Initial & iness & Prolong & iciness & Fruits & & Fruits & ness & Fruit ${ }_{1}$ & ness \\
\hline \multirow{4}{*}{$\begin{array}{l}\text { Vidovka } \\
\text { Crvena }\end{array}$} & $\bar{x}$ & $s_{\ddot{x}}$ & $\bar{x}$ & $s_{\bar{x}}$ & $\bar{x}$ & $s_{\widetilde{x}}$ & $\bar{x}$ & $s_{\tilde{x}}$ & $\bar{x}$ & $s_{\bar{x}}$ & $\bar{x}$ & $s_{\bar{X}}$ & $\bar{x}$ & $s_{\bar{x}}$ & $\bar{x}$ & $s_{\bar{x}}$ & $\bar{x}$ & $s_{\bar{x}}$ \\
\hline & 5.29 & 0.56 & 5.43 & 0.46 & 4.29 & 0.39 & 4.29 & 0.31 & 5.14 & 0.37 & 5.71 & 0.20 & 5.29 & 0.39 & 3.14 & 0.28 & 4.29 & 0.31 \\
\hline & & & $\mathrm{ab}$ & & & & & & $\mathrm{ab}$ & & b & & $\mathrm{cd}$ & & $\mathrm{ab}$ & & $\mathrm{bc}$ & \\
\hline & 5.57 & 0.52 & 4.71 & 0.51 & 4.57 & 0.32 & 4.57 & 0.32 & 4.86 & 0.28 & 5.43 & 0.40 & 4.71 & 0.20 & 3.00 & 0.24 & 4.29 & 0.31 \\
\hline Vidovka Žuta & & & $\mathrm{ab}$ & & & & & & $\mathrm{ab}$ & & $\mathrm{ab}$ & & bcd & & $\mathrm{ab}$ & & $\mathrm{bc}$ & \\
\hline \multirow[t]{2}{*}{ Petrovača } & 5.14 & 0.60 & 5.00 & 0.53 & 4.71 & 0.69 & 5.43 & 0.40 & 4.71 & 0.45 & 4.29 & 0.51 & 3.86 & 0.80 & 2.29 & 0.45 & 3.00 & 0.71 \\
\hline & & & $a b$ & & & & & & $\mathrm{ab}$ & & $\mathrm{ab}$ & & $a b c$ & & a & & $a b c$ & \\
\hline \multirow{3}{*}{$\begin{array}{c}\text { Petrovka } \\
\text { Crvena }\end{array}$} & 7.00 & 0.24 & 6.71 & 0.31 & 4.71 & 0.65 & 3.57 & 0.70 & 5.43 & 0.57 & 5.29 & 0.39 & 5.71 & 0.73 & 3.14 & 0.64 & 3.33 & 0.62 \\
\hline & & & b & & & & & & b & & $\mathrm{ab}$ & & $\mathrm{d}$ & & $\mathrm{ab}$ & & $a b c$ & \\
\hline & 4.71 & 0.99 & 4.43 & 0.91 & 3.71 & 0.81 & 5.57 & 0.81 & 4.29 & 0.81 & 3.71 & 0.73 & 3.29 & 0.73 & 4.14 & 0.89 & 1.43 & 0.32 \\
\hline Đedovača & & & a & & & & & & $\mathrm{ab}$ & & ab & & $a b c$ & & abcd & & a & \\
\hline \multirow[t]{3}{*}{ Gospoinjača } & 5.71 & 0.39 & 6.00 & 0.24 & 5.43 & 0.22 & 4.43 & 0.22 & 5.14 & 0.60 & 5.00 & 0.47 & 4.14 & 0.28 & 3.43 & 0.40 & 2.71 & 0.39 \\
\hline & & & ab & & & & & & $\mathrm{ab}$ & & $\mathrm{ab}$ & & $a b c$ & & $a b c$ & & $a b c$ & \\
\hline & 5.86 & 0.28 & 5.71 & 0.56 & 5.43 & 0.66 & 5.57 & 0.22 & 5.71 & 0.45 & 5.00 & 0.33 & 4.71 & 0.45 & 4.43 & 0.32 & 2.43 & 0.57 \\
\hline \multirow{2}{*}{ Vinjugara } & & & $\mathrm{ab}$ & & & & & & b & & $\mathrm{ab}$ & & bcd & & bcd & & $\mathrm{ab}$ & \\
\hline & 6.14 & 0.28 & 5.57 & 0.32 & 3.43 & 0.40 & 4.71 & 0.39 & 3.14 & 0.16 & 3.57 & 0.57 & 3.86 & 0.37 & 3.57 & 0.32 & 4.86 & 0.60 \\
\hline Kolačara & & & ab & & & & & & a & & a & & $a b c$ & & $a b c$ & & c & \\
\hline \multirow[t]{3}{*}{ Šipunja } & 6.00 & 0.24 & 5.71 & 0.20 & 5.00 & 0.33 & 5.14 & 0.44 & 4.71 & 0.45 & 4.14 & 0.55 & 2.29 & 0.65 & 5.43 & 0.46 & 2.14 & 0.80 \\
\hline & & & $a b$ & & & & & & $\mathrm{ab}$ & & $\mathrm{ab}$ & & a & & $\mathrm{cd}$ & & $\mathrm{ab}$ & \\
\hline & 5.86 & 0.16 & 5.71 & 0.20 & 4.86 & 0.16 & 5.14 & 0.37 & 4.86 & 0.49 & 4.00 & 0.24 & 2.57 & 0.40 & 6.00 & 0.24 & 1.57 & 0.22 \\
\hline Šarenika & & & $\mathrm{ab}$ & & & & & & $\mathrm{ab}$ & & $\mathrm{ab}$ & & $\mathrm{ab}$ & & $\mathrm{d}$ & & a & \\
\hline $\mathrm{F}$ & 1.83 & & $2.09^{*}$ & & 1.93 & & 2.05 & & $2.28^{*}$ & & $3.07^{* *}$ & & $6.64^{* *}$ & & $6.93^{* *}$ & & $6.07^{* *}$ & \\
\hline
\end{tabular}

*Indicating $\mathrm{p}<0.05 ;$; indicating $\mathrm{p}<0.01$, according to ANOVA F values and related significance scores; abc... letters indicate significant differences and grouping of the cultivars according to Tukey's multiple range tests with $95 \%$ significance 

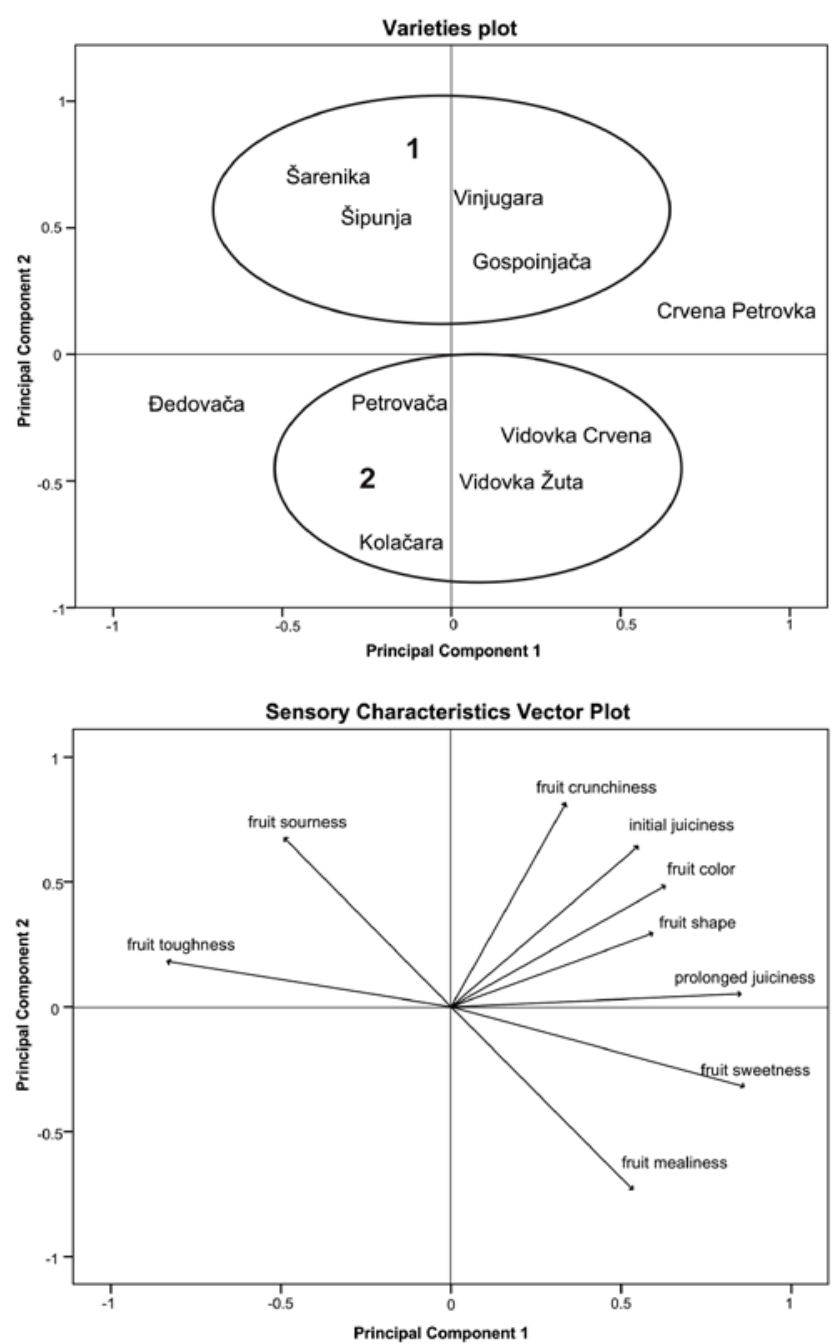

Fig. 1. Principal components analyses of studied apple varieties (down) with vectors of measured sensory characteristics (up)

The principal components analysis distinguished two principal components which together covered $68.77 \%$ of the variations (Fig. 2). The principal component 1 (46.12\% of the variations) included the highest impacts related to the size of the fruit in positive direction, and the length of the stalk in opposite direction. The principal component 2 (22.65\% variations) mostly comprised variations under the influence of soluble solids content and thickness of the fruit stalk. Out of the tested cultivars, two main groups were distinctive. The first group comprised the largest number of varieties that were not characterized by a large number of extreme values of the measured pomological fruit properties. The second group comprised 'Gospoinjača' and 'Kolačara' characterized by a greater amount of soluble solids content, an increased firmness and increased thickness of the fruit stalk. In particular, 'Vinjugara' was distinctive for the largest fruits, while 'Petrovača' had the smallest fruits.

Pomological characteristics of the fruits of indigenous fruit trees are important in terms of maintaining biodiversity as well as the desirable traits in breeding program and for breeding of highly nutritious fruits for commercial production (Miletić et al., 2003). Given that the content of soluble solids of fruit is a very important indicator of fruit quality which particularly affects the flavor of the fruit, the variety "Gospoinjacca' singled out with $15.78{ }^{\circ}$ Brix, followed by a low content of organic acids (0.59\%), implying a
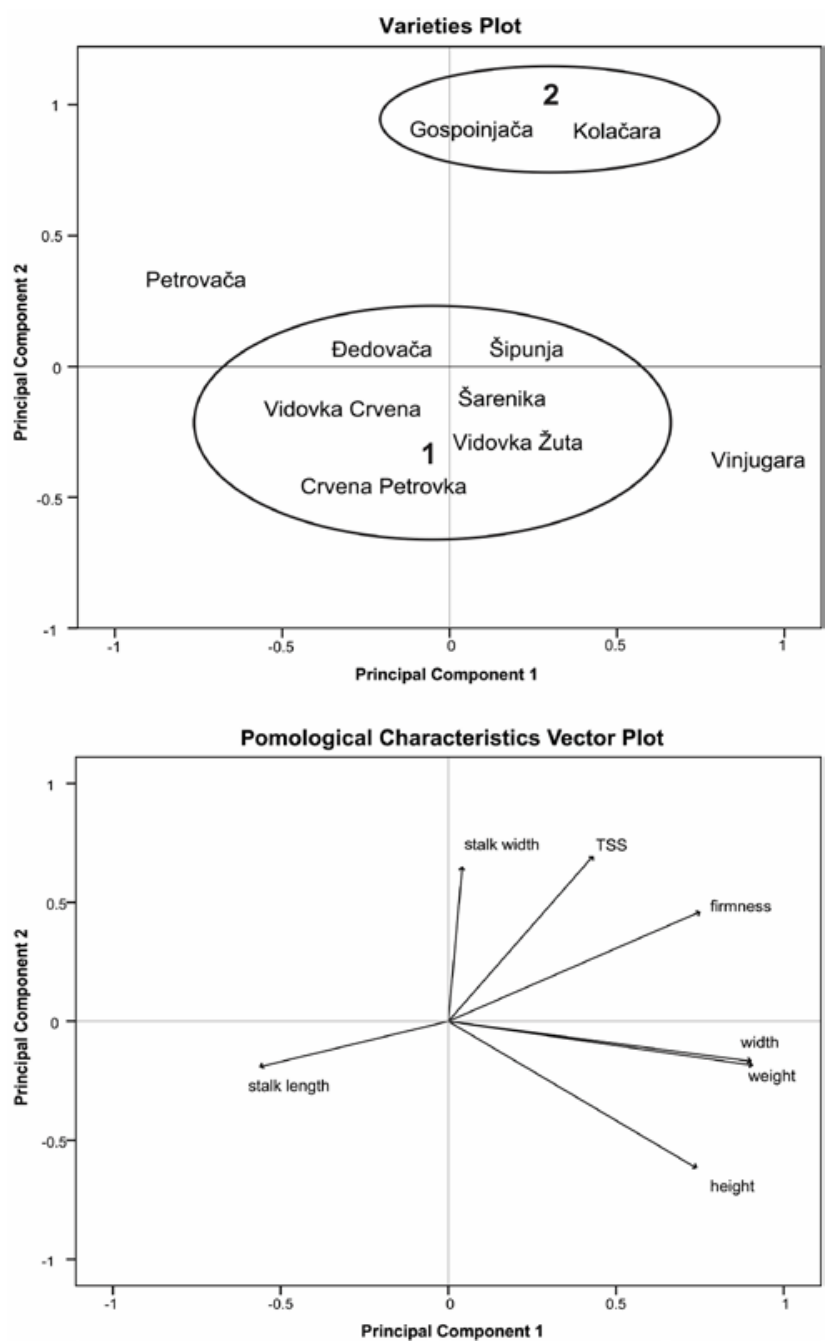

Fig. 2. Principal components analysis of studied apple varieties (up) with vectors of measured pomological characteristics (down)

favorable relation between the tested characteristics that are important for the acceptance of a variety by consumers (Mratinic and Fortirić Akšić, 2012). Compared to the indigenous assortment studied in the region of Serbia, where the soluble solid content of the fruit flesh reaches values up to $19.24^{\circ}$ Brix and Iran up to $18.0^{\circ} \mathrm{Brix}$ (Farrokhi et al., 2013) our varieties did not show a significant content (12.25-15.78 $\left.{ }^{\circ} \mathrm{Brix}\right)$ but well fit in the results of the assortment of apples from the region of Turkey with the highest ${ }^{\circ}$ Brix of 15.0 (Gradinariu et al., 2003). These results can be linked to the fact that the content of soluble solids in the cell juice of the fruit depends on the environmental conditions and agricultural technology (Nilsson and Gustavsson, 2006). If the same results are compared with the results of representative commercial apple cultivars: 'Gala' $14.6{ }^{\circ} \mathrm{Brix}$ (Faramarzi et al., 2014), 'Breaburn' $14.3^{\circ}$ Brix, 'Fuji' $15.6^{\circ}$ Brix, 'Granny Smith' 11.9 ${ }^{\circ}$ Brix (Corollaroa et al., 2013), the variety 'Gospoinjača' singled out by slightly higher values whilst the remaining of tested varieties did not gain importance in relation to commercial varieties by testing ${ }^{\circ}$ Brix in the pulp of the fruit. Firmness of the flesh of the tested assortment of apple fruits ranged from $4.91 \mathrm{~kg} \mathrm{~cm}^{-2}$ in the cultivar 'Petrovača' which had the lowest fruit weight $(63.77 \mathrm{~g})$ to $11.38 \mathrm{~kg}$ $\mathrm{cm}^{-2}$ in the variety 'Kolačara' which fully fitted in the research results of Croatian apple germplasm. 'Kolačara' in addition to significant firmness and a satisfactory soluble solids content $(15.12$ 
Table 2. Mean values $(\vec{x})$ and standard errors $( \pm)\left(s_{x}\right)$ of the pomological characteristics of the studied autochthonous apple cultivars from Bosnia and Herzegovina

\begin{tabular}{|c|c|c|c|c|c|c|c|c|c|c|c|c|c|c|}
\hline \multirow{2}{*}{ Cultivar } & \multicolumn{2}{|c|}{$\begin{array}{c}\text { Weight } \\
{[\mathrm{g}]}\end{array}$} & \multicolumn{2}{|c|}{$\begin{array}{l}\text { Firmness } \\
{\left[\mathrm{N} \mathrm{cm}^{-2}\right]} \\
\end{array}$} & \multicolumn{2}{|c|}{$\begin{array}{c}\text { TSS } \\
{\left[{ }^{\circ} \text { Brix }\right]}\end{array}$} & \multicolumn{2}{|c|}{$\begin{array}{c}\text { Fruit height } \\
{[\mathrm{mm}]}\end{array}$} & \multicolumn{2}{|c|}{$\begin{array}{c}\text { Fruit width } \\
{[\mathrm{mm}]}\end{array}$} & \multicolumn{2}{|c|}{$\begin{array}{l}\text { Stalk length } \\
{[\mathrm{mm}]}\end{array}$} & \multicolumn{2}{|c|}{$\begin{array}{l}\text { Stalk width } \\
{[\mathrm{mm}]}\end{array}$} \\
\hline & $\overline{\mathrm{x}}$ & $s_{\bar{x}}$ & $\overline{\mathrm{x}}$ & $s_{\bar{x}}$ & $\overline{\mathrm{x}}$ & $s_{\bar{x}}$ & $\overline{\mathrm{x}}$ & $s_{\bar{x}}$ & $\bar{x}$ & $s_{\bar{x}}$ & $\bar{x}$ & $s_{\bar{x}}$ & $\bar{x}$ & $s_{\bar{x}}$ \\
\hline \multirow{2}{*}{$\begin{array}{l}\text { Vidovka } \\
\text { Crvena }\end{array}$} & 82.44 & 2.65 & 7.84 & 0.21 & 12.25 & 0.24 & 54.25 & 1.34 & 58.48 & 1.17 & 7.88 & 0.50 & 4.80 & 0.34 \\
\hline & $a b$ & & $\mathrm{bc}$ & & a & & $a b c$ & & $a b$ & & $a b c$ & & $a b c$ & \\
\hline \multirow{2}{*}{ Vidovka Žuta } & 85.70 & 7.94 & 7.18 & 0.25 & 12.33 & 0.19 & 62.62 & 1.50 & 72.01 & 1.18 & 6.45 & 0.34 & 4.98 & 0.15 \\
\hline & $\mathrm{ab}$ & & b & & a & & de & & ef & & $a b$ & & $a b c$ & \\
\hline \multirow{2}{*}{ Petrovača } & 63.77 & 3.97 & 4.91 & 0.26 & 13.36 & 0.45 & 48.32 & 1.34 & 55.16 & 1.55 & 17.19 & 1.89 & 5.68 & 0.23 \\
\hline & a & & a & & $a b c$ & & a & & a & & e & & $\mathrm{bc}$ & \\
\hline \multirow{2}{*}{$\begin{array}{l}\text { Crvena } \\
\text { Petrovka }\end{array}$} & 115.59 & 4.52 & 5.21 & 0.19 & 13.48 & 0.33 & 56.87 & 1.32 & 66.69 & 1.05 & 14.01 & 1.26 & 4.31 & 0.26 \\
\hline & $\mathrm{cd}$ & & a & & $a b c$ & & bcd & & cde & & de & & $a b$ & \\
\hline \multirow{2}{*}{ Đedovača } & 80.43 & 7.10 & 8.84 & 0.31 & 12.83 & 0.28 & 50.08 & 1.47 & 53.52 & 0.99 & 7.93 & 0.80 & 3.75 & 0.28 \\
\hline & $a b$ & & c & & $\mathrm{ab}$ & & a & & a & & $a b c$ & & a & \\
\hline \multirow{2}{*}{ Gospoinjača } & 93.62 & 6.75 & 10.38 & 0.19 & 15.78 & 0.26 & 51.65 & 1.79 & 61.65 & 1.70 & 9.84 & 0.61 & 4.86 & 0.41 \\
\hline & $\mathrm{bc}$ & & de & & $\mathrm{f}$ & & $\mathrm{ab}$ & & $\mathrm{bc}$ & & $\mathrm{bc}$ & & $a b c$ & \\
\hline \multirow{2}{*}{ Vinjugara } & 208.97 & 11.69 & 10.60 & 0.26 & 13.96 & 0.34 & 67.21 & 2.13 & 80.23 & 1.95 & 6.42 & 0.82 & 4.53 & 0.58 \\
\hline & e & & de & & bcd & & e & & $\mathrm{g}$ & & $a b$ & & $a b c$ & \\
\hline \multirow{2}{*}{ Kolačara } & 138.04 & 5.49 & 11.38 & 0.39 & 15.12 & 0.36 & 52.62 & 1.02 & 73.16 & 1.28 & 4.00 & 0.23 & 6.01 & 0.25 \\
\hline & d & & f & & $\mathrm{df}$ & & $a b c$ & & $\mathrm{f}$ & & a & & c & \\
\hline \multirow{2}{*}{ Šipunja } & 139.09 & 6.97 & 10.08 & 0.22 & 14.34 & 0.23 & 58.75 & 1.54 & 65.96 & 1.51 & 11.82 & 0.36 & 4.71 & 0.55 \\
\hline & d & & d & & $\mathrm{cd}$ & & $\mathrm{cd}$ & & $\mathrm{cd}$ & & $\mathrm{cd}$ & & $a b c$ & \\
\hline \multirow{2}{*}{ Šarenika } & 137.30 & 6.58 & 8.48 & 0.22 & 14.20 & 0.35 & 57.52 & 1.07 & 68.18 & 1.00 & 16.02 & 1.53 & 4.06 & 0.31 \\
\hline & d & & c & & $\mathrm{cd}$ & & bcd & & def & & $\mathrm{e}$ & & a & \\
\hline $\mathrm{F}$ & $40.09^{*}$ & & $75.61^{*}$ & & $13.65^{\circ}$ & & $15.49^{\circ}$ & & $37,85^{\circ}$ & & $20.23^{*}$ & & $3.63^{\circ}$ & \\
\hline
\end{tabular}

*Indicating $\mathrm{p}<0.05$; **indicating $\mathrm{p}<0.01$, according to ANOVA F values and related significance scores; abc... letters indicate significant differences and grouping of the cultivars according to Tukey's multiple range tests with $95 \%$ significance

${ }^{\circ}$ Brix), was also characterized by the greatest length and width of stalks, and in comparison to the variety of fruit carrying the same name from the region of Montenegro (Božović et al., 2013) recorded similar weight values, width and height of the fruit, considering minor variations $(138.04 / 142.20 \mathrm{~g} ; 52.62 / 52.71 \mathrm{~mm}$; $73.16 / 75.86 \mathrm{~mm})$. In addition to suitable pomological characteristics, 'Kolačara' had a good free radical scavenging activity which is in full correlation with high content of total phenols and thus stood out as an interesting cultivar for a breeding program in order to obtain varieties resistant to stress factors, good nutritional properties and an extended period for storage. Comparing the cultivar 'Šarenika' from the same region with our eponymous cultivar, similar values were observed relating to the width and height of the fruit however with somewhat greater fruit weight of 'Šarenika' from our area The differences in the weight of tested varieties were significant, and that is in full compliance with the studied assortment of apples from Serbia (70.0-193.3 g), varieties of Montenegro (62.2-182.3 g) and varieties from the region of Turkey (60.8-242.2 g). The 'Vinjugara' cultivar singled out with the largest fruits but that is not so important if compared to the varieties from the area of Turkey recording the largest fruit weight of $310.99 \mathrm{~g}$ (Kaya et al., 2015). It can also be concluded that commercial varieties in intensive production plantings reach much higher fruit weight compared to the studied indigenous varieties grown under in situ conditions where the cultivar 'Breaburn' recorded weight of $221 \mathrm{~g}$, 'Fuji' $247 \mathrm{~g}$ while 'Granny Smith' reached $257 \mathrm{~g}$ (Corollaro et al., 2013).

\section{Biochemical characteristics}

Analysis of variance of measured biochemical characteristics showed that the indigenous varieties tested statistically demonstrate significant differences in $\mathrm{pH}$ values, the amount of dry matter, titratable acidity (TA), the content of phenols and flavonoids (Table 3).

Statistically significant difference between the tested varieties have not been found for antioxidant activity evaluated as free radical scavenging activity (for short marked as A-oxy activity in Table 3) and the content of vitamin C, although for these features indicative measured differences between varieties do exist. The lowest $\mathrm{pH}$ value was characteristic of 'Vidovka Crvena' (3.08) and the highest for 'Kolačara' (4.17), by which both of them significantly differ from the rest of the tested cultivars. 'Vidovka Crvena' specifically differed with a low proportion of dry matter (13.77\%), and statistically significantly highest proportion of dry matter was measured again in 'Kolačara' (20.72\%). A low proportion of organic acids was found in 'Kolačara' $0.21 \%$, whilst the highest TA was found in 'Vidovka Crvena' (1.08\%). In comparison to all varieties tested statistically most significant amount of phenols and flavonoids was found in the variety 'Đedovača', whilst the cultivars ‘ Šarenika', 'Vinjugara' and 'Vidovka Crvena' stood out as a group with low levels of flavonoids and phenols.

The principal components analysis distinguished two principal components which together included $78.01 \%$ of the variations (Fig. 3). The principal component 1 (54.39\% of the variations) comprised most influences to the amount of $\mathrm{pH}$ and vitamin $\mathrm{C}$ in positive direction, and DPPH radical scavenging ability in the opposite direction. The principal component 2 (23.62\% variation) mostly comprised the variations influenced by TA share in positive direction, and the dry matter share in negative direction. The tested indigenous cultivars were grouped into three groups according to the measured biochemical characteristics of the fruit. The first group consisted of 'Crvena Petrovka', 'Petrovača', 
102

'Vidovka Žuta' and 'Šipunja', which are located in the middle of the diagram and are primarily characterized by the mean value of the measured biochemical characteristics. The second group, which comprised 'Vidovka Crvena', 'Šarenika' and 'Vinjugara', was characterized by a low $\mathrm{pH}$, a smaller amount of vitamin $\mathrm{C}$, a smaller content of phenols and flavonoids, and lower free radical scavenging ability and TA. The third group, which comprised 'Gospoinjača' and 'Kolačara' was characterized primarily by high proportion of dry matter, a greater amount of vitamin C, low TA and increased $\mathrm{pH}$. Indigenous cultivar 'Đedovača' was singled out especially for a large amount of flavonoids and phenols, and high free radical scavenging ability.

It turned out that the analyzed varieties were correctly selected because they had a substantial content of secondary metabolites in comparison to literature data available for the varieties of apples grown regionally. Mitić et al. (2013) have analyzed 15 varieties of apples grown in Serbia and found that the total phenols content varies from 72 to $217 \mathrm{mg} \mathrm{GAE} / 100 \mathrm{~g} \mathrm{FW}$, which also applies to apples grown in Bulgaria with $126 \mathrm{mg} \mathrm{GAE} / 100 \mathrm{~g} \mathrm{FW}$ (Deneuve et al., 2013). Śavikin et al. (2014) found that total phenols content in four Serbian autochthonous varieties was the highest in the bark having a defensive role (Veberič et al., 2010) and being within a very wide range (9.37 to $1440 \mathrm{mg} \mathrm{GAE} / 100 \mathrm{~g} \mathrm{FW}$ ). Indigenous varieties are expected to have a higher total phenols content compared to commercial varieties, as confirmed by comparison of three indigenous and three commercial varieties of Bosnia and Herzegovina (Begić-Akagić et al., 2011). Large variations in the content of total phenols in the fruits of the same apple trees, monitored in two consecutive seasons, were shown in a study of 19 varieties of apples grown in Romania, where the difference reached up to $800 \mathrm{mg} \mathrm{GAE} / 100 \mathrm{~g} \mathrm{FW}$ (Delian et al., 2011). It is interesting that phenols are differently concentrated in the bark, seeds and flesh of the fruit (Francini and Sebastiani, 2013; Savikin et al., 2014). The most common phenolic compounds in the apples are flavonoids the concentration of which mostly depends on the variety of apples (Yuri et al., 2014). The content of total flavonoids in the study Mitic et al. (2013) ranged from 37 to 112 $\mathrm{mg} \mathrm{CE} / 100 \mathrm{~g} \mathrm{FW}$, which is less than that of our indigenous varieties where only three varieties had less than $100 \mathrm{mg} \mathrm{CE} / 100 \mathrm{~g}$ $\mathrm{FW}$. Due to a low content of vitamin C, compared with literature data (Kevers et al., 2011; Lee et al., 2003; Šavikin et al., 2014), it is obvious that good free radical scavenging activity of our tested varieties is a result of high content of phenols and flavonoids, which is in line with previous findings that vitamin C represents only a small portion of the total antioxidant activity in apples (Lee $e t$ al., 2003). Indigenous varieties of Bosnia and Herzegovina, like our analyzed varieties, had similar content of vitamin $\mathrm{C}$, about 1 $\mathrm{mg} / 100 \mathrm{~g} \mathrm{FW}$, while the commercial cultivars had the contents of L-ascorbic acid up to $4 \mathrm{mg} / 100 \mathrm{~g} \mathrm{FW}$ (Begić-Akagić et al., 2011). Varieties often differ considerably in content of TA which affects the taste of an apple. The same trend is observed in our old varieties in this research, but also in other apple varieties of the Balkan region (Jacopic et al., 2012; Šavikin et al., 2014). Excellent adaptability of indigenous varieties to changing climatic conditions and stress is a result of production of secondary metabolites in greater quantities than in commercial varieties, resulting in better nutritional value of these varieties, as well as in a richer flavor (Lutaladio et al., 2010). Aroma is very important to consumers, and it depends on the content of sugar, organic acids, phenols, flavonoids and other secondary metabolites. Too high phenolic content may contribute to a less attractive pungent taste (Delian et al., 2011). An interesting study was done on the impact of phenols extracted from apples to the content of total and LDL cholesterol levels in obese individuals which showed that phenols in the

Table 3. Mean values $(\overrightarrow{\mathrm{x}})$ and standard errors $( \pm)\left(s_{\mathrm{x}}\right)$ of the biochemical characteristics of the studied autochthonous apple cultivars from Bosnia and Herzegovina

\begin{tabular}{|c|c|c|c|c|c|c|c|c|c|c|c|c|c|c|}
\hline \multirow[t]{2}{*}{ Cultivar } & \multicolumn{2}{|c|}{$\begin{array}{c}\text { A-oxi. activity } \\
{\left[\mathrm{mg} \mathrm{ml}^{-1}\right]}\end{array}$} & \multicolumn{2}{|c|}{$\mathrm{pH}$} & \multicolumn{2}{|c|}{$\begin{array}{c}\text { Dry matter } \\
{[\%]}\end{array}$} & \multicolumn{2}{|c|}{$\begin{array}{c}\text { Titrable acidity } \\
{[\%]} \\
\end{array}$} & \multicolumn{2}{|c|}{$\begin{array}{c}\text { C vitamin } \\
{\left[\mathrm{mg} \mathrm{g}^{-2}\right]}\end{array}$} & \multicolumn{2}{|c|}{$\begin{array}{c}\text { Phenols } \\
{\left[\mathrm{mgGAE} \mathrm{g}^{-2}\right]}\end{array}$} & \multicolumn{2}{|c|}{$\begin{array}{l}\text { Flavonoids } \\
{\left[\mathrm{mgCE} \mathrm{g}^{-2}\right]} \\
\end{array}$} \\
\hline & $\overline{\mathrm{x}}$ & $S_{\bar{x}}$ & $\bar{x}$ & $S_{\bar{x}}$ & $\bar{x}$ & $S_{\bar{x}}$ & $\bar{x}$ & $\mathrm{~S}_{\overline{\mathrm{x}}}$ & $\bar{x}$ & $\mathrm{~S}_{\overline{\mathrm{x}}}$ & $\bar{x}$ & $s_{\bar{x}}$ & $\bar{x}$ & $s_{\bar{x}}$ \\
\hline \multirow{2}{*}{$\begin{array}{l}\text { Vidovka } \\
\text { Crvena }\end{array}$} & 52.77 & 14.09 & 3.08 & 0.05 & 13.77 & 0.93 & 1.08 & 0.05 & 0.65 & 0.05 & 243.32 & 42.93 & 62.26 & 19.05 \\
\hline & & & $\mathrm{a}$ & & a & & c & & & & a & & a & \\
\hline \multirow{2}{*}{$\begin{array}{l}\text { Vidovka } \\
\text { Žuta }\end{array}$} & 33.02 & 24.30 & 3.71 & 0.31 & 14.75 & 0.06 & 0.70 & 0.21 & 1.01 & 0.11 & 374.25 & 120.71 & 163.11 & 48.72 \\
\hline & & & $a b c$ & & $a b$ & & bc & & & & a & & $a b$ & \\
\hline \multirow{2}{*}{ Petrovača } & 14.33 & 8.64 & 3.77 & 0.27 & 14.72 & 1.96 & 0.64 & 0.17 & 1.19 & 0.20 & 371.13 & 24.70 & 157.07 & 34.21 \\
\hline & & & $\mathrm{bc}$ & & $a b$ & & bc & & & & a & & $a b$ & \\
\hline \multirow{2}{*}{$\begin{array}{l}\text { Crvena } \\
\text { Petrovka }\end{array}$} & 36.37 & 6.49 & 3.23 & 0.04 & 14.99 & 0.04 & 0.77 & 0.01 & 0.99 & 0.25 & 950.59 & 312.03 & 128.95 & 35.60 \\
\hline & & & $a b$ & & $a b$ & & bc & & & & $a b$ & & $a b$ & \\
\hline \multirow{2}{*}{ Đedovača } & 11.10 & 7.51 & 3.54 & 0.14 & 15.26 & 0.44 & 0.93 & 0.00 & 0.94 & 0.11 & 1711.8 & 427.73 & 222.94 & 54.62 \\
\hline & & & $a b$ & & $a b$ & & $\mathrm{bc}$ & & & & b & & b & \\
\hline \multirow{2}{*}{$\begin{array}{l}\text { Gospoinja } \\
\text { ča }\end{array}$} & 27.36 & 17.26 & 3.37 & 0.04 & 18.72 & 0.33 & 0.59 & 0.04 & 1.28 & 0.30 & 565.00 & 148.10 & 107.29 & 32.06 \\
\hline & & & $a b$ & & bc & & b & & & & a & & $a b$ & \\
\hline \multirow{2}{*}{ Vinjugara } & 43.93 & 0.86 & 3.15 & 0.04 & 18.67 & 0.13 & 0.95 & 0.03 & 0.75 & 0.09 & 258.34 & 63.18 & 44.42 & 9.96 \\
\hline & & & $a b$ & & bc & & bc & & & & a & & a & \\
\hline \multirow{2}{*}{ Kolačara } & 20.53 & 16.73 & 4.17 & 0.05 & 20.72 & 0.97 & 0.21 & 0.01 & 1.25 & 0.24 & 859.38 & 292.91 & 150.43 & 4.50 \\
\hline & & & c & & c & & a & & & & $a b$ & & $a b$ & \\
\hline \multirow{2}{*}{ Šipunja } & 27.57 & 18.87 & 3.21 & 0.03 & 18.07 & 0.34 & 0.67 & 0.11 & 0.83 & 0.04 & 993.20 & 366.73 & 102.93 & 6.70 \\
\hline & & & $\mathrm{ab}$ & & $a b c$ & & bc & & & & $a b$ & & $a b$ & \\
\hline \multirow{2}{*}{ Šarenika } & 29.14 & 5.98 & 3.22 & 0.03 & 15.72 & 1.91 & 0.64 & 0.07 & 0.62 & 0.10 & 294.81 & 51.44 & 79.07 & 17.34 \\
\hline & & & $\mathrm{ab}$ & & $a b$ & & $\mathrm{bc}$ & & & & a & & a & \\
\hline F & 0,84 & & $6.21^{* *}$ & & $5.46^{* \prime}$ & & $6.11^{* *}$ & & & & & & & $2.99^{*}$ \\
\hline
\end{tabular}

*Indicating $\mathrm{p}<0.05 ;{ }^{* *}$ indicating $\mathrm{p}<0.01$, according to ANOVA F values and related significance scores; ${ }^{\text {abc... }}$ letters indicate significant differences and grouping of the cultivars according to Tukey's multiple range tests with $95 \%$ significance 

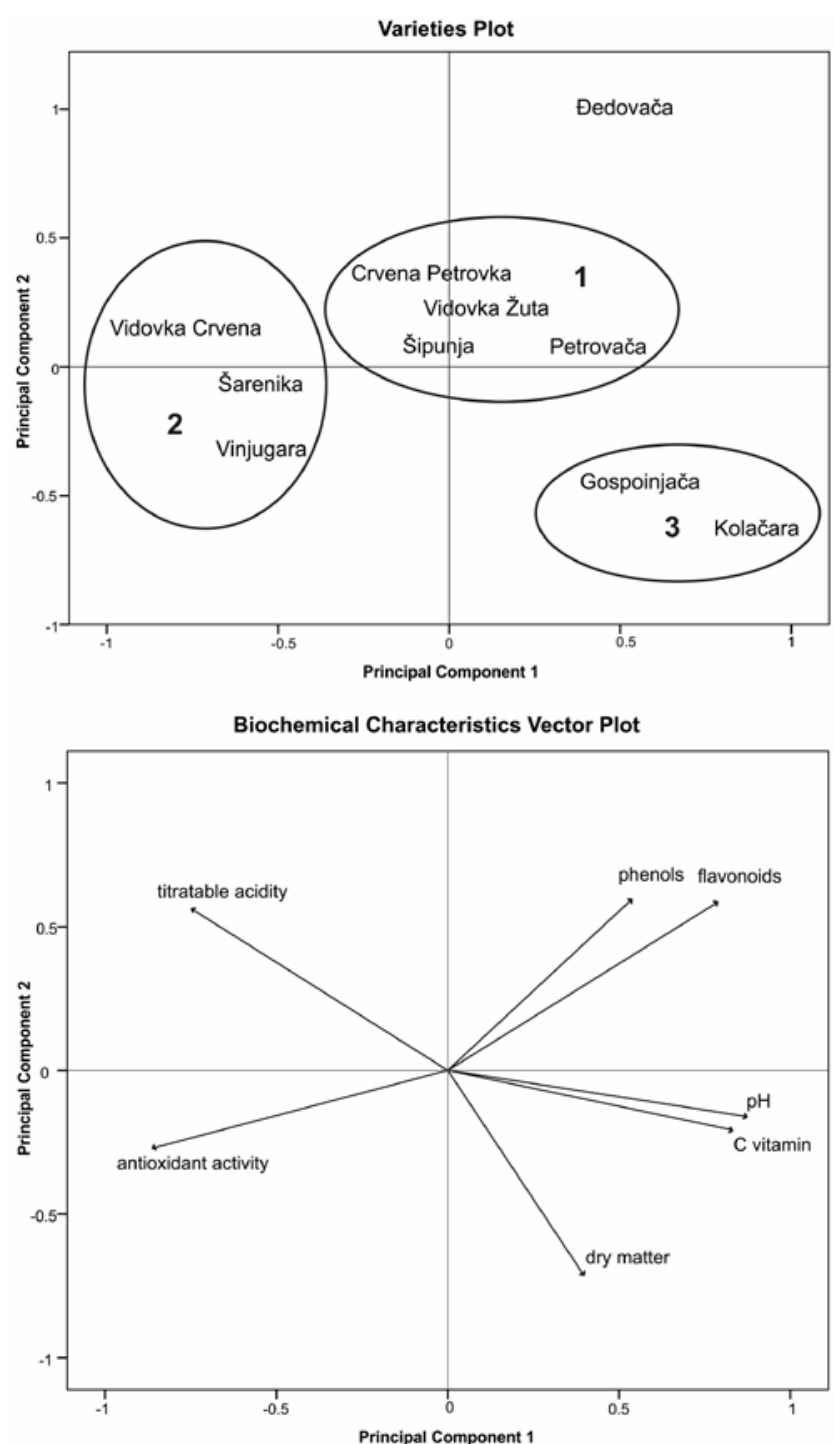

Fig. 3. Principal Components Analysis of studied apple varieties (up) with vectors of measured biochemical characteristics (down)

concentration of $600 \mathrm{mg} /$ day significantly reduced the content of total and LDL cholesterol, and therefore recommended a daily intake of apples (Nagasako-Akazome et al., 2007).

\section{Conclusions}

These are the first results on pomological and biochemical characteristics of the ten analyzed apple accessions/varieties from the territory of Bosnia and Herzegovina. The varieties 'Kolačara' and 'Gospoinjača' showed good pomological and biochemical characteristics, primarily for good ratio between firmness and ${ }^{\circ}$ Brix but also a significant amount of vitamin $\mathrm{C}$ which was fully in accordance with lesser proportion of acids in fruits. On the other side, 'Đedovača' showed good nutritional characteristics, primarily a considerable phenols content and good DPPH radical scavenging activity, compounds which have important function in the field of pharmacy and medicine for their antioxidant and anticarcinogenic potential in the prevention of many diseases. Good characteristics of the fruit quality of these accessions/varieties represent an important reference in selection of materials for breeding programs aimed at improving the characteristics of the domestic apple germplasm, primarily nourishing properties but also for extended storage time of the fruits.

\section{Acknowledgements}

103

This work was supported by the Ministry of Science and Technology of the Republic of Srpska, Bosnia and Herzegovina, grant number 19/06-020/961-158-1/11.

\section{References}

AOAC (1990). Official Methods of Analysis of the Association of Official Analytical Chemists. 15th Edition, Arlington.

Begić-Akagić A, Spaho N, Oručević S, Drkenda P, Kurtović M, Gaši F, Kopjar M, Piližota V (2011). Influence of cultivar, storage time, and processing on the phenol content of cloudy apple juice. Croatian Journal of Food Science and Technology 3(2):1-8.

Salkić B (2012). Characterization of autohtonous genofond pears from Bosnia and Herzegovina. PhD Thesis, University of Banja Luka, Bosnia and Herzegovina.

Beširević B (2009). Autohtone jabuke i kruške sa prostora Bosne i Hrecegovine (local apples and pears from the Bosnia and Herzegovina). Harfo-graf, Tuzla, Bosnia and Hercegovina.

Bignami C, Scossa A, Vagnoni G (2003). Evaluation of old italian apple cultivars by means of sensory analysis. Acta Horticulturae 598:85-90.

Božović D, Jaćimović V, Lazović B (2013). Old apple varieties in Central Montenegro. Agriculture and Forestry 59(2):217-223.

Corollaro ML, Endrizzi I, Bertolini A, Aprea E, Dematte ML, Costa F, Biasioli F, Gasperi F (2013). Sensory profiling of apple: Methodological aspects, cultivar characterization and postharvest changes. Postharvest Biology and Technology 77:111-120.

Dan C, Serban C, Sestras A, Militaru M, Morariu P, Sestras R (2015). Consumer perception concerning apple fruit quality, depending on cultivars and hedonic scale of evaluation - a case study. Notulae Scientia Biologicae 7(1):140-149.

Delian E, Petre V, Burzo I, Badulescu L, Hoza D (2011). Total phenols and nutrients composition aspects of some apple cultivars and new studied breeding creations lines grown in Voinesti area - Romania. Romanian Biotechnological Letters 16(6):6722-6729.

Denev P, Lojek A, Ciz M, Kratchanova M (2013). Antioxidant activity and polyphenol content of Bulgarian fruits. Bulgarian Journal of Agricultural Science 19(1):22-27.

Đurić G, Mićić N, Salkić B (2014). Evaluation of Pear (Pyrus communis L.) germplasm collected in Bosnia and Herzegovina using some pomological and ecophysiological characteristics. Acta Horticulturae 1032:105-115.

Đurić G, Tomić L, Mićić N, Cvetković M, Radoš Lj, Pašalić B (2009). Fruit genetic resources in Republika Srpska. Acta Agriculturae Serbica 15(28):31-40.

Đurić G, Žabić M, Rodić M, Stanivuković S, Bosančić B, Pašalić B (2015). Biochemical and pomological assessment of European pear accessions from Bosnia and Herzegovina. Horticultural Science (Prague) 42(4):176-184.

Đurić G, Lolić B, Kajkut Zeljković M, Delić D, Koprivica M, Radulović M, Nikolić P, Mićić N, Erić Ž (2016). Sanitary status of pome and stone fruit collection in gene bank in Republic of Srpska. Agro-knowledge Journal 16(1):121-133.

Faramarzi Sh, Yadollahi A, Barzegar M, Sadraei K, Pacifico S, Jemrić T (2014). Comparison of phenolic compounds' content and antioxidant 
104

activity between some native iranian apples and standard cultivar 'Gala'. Journal of Agricultural Science and Technology 16:1601-1611.

Farrokhi J, Darvishzadeh R, Maleki HH, Naseri L (2013). Evaluation of Iranian native apple (Malus $\times$ domestica Borkh) gerpmlasm using biochemical and morfological characteristics. Agriculture Conspectus Scientificus 78(4):307-313

Francini A, Sebastiani L (2013). Phenolic compounds in apple (Malus $\times$ domestica Borkh.): compounds characterization and stability during postharvest and after processing. Antioxidants 2(3):181-193.

Gaši F, Simon S, Pojskic N, Kurtovic M, Pejić I (2010). Genetic assessment of apple germplasm in Bosnia and Herzegovina using microsatellite and morphologic markers. Scientia Horticulturae 126(2):164-171.

Gradinariu G, Istrate M, Dascalu M, Gradinariu F (2003). Native apple germplasm in Romania. Acta Horticulturae 622:485-488.

Iezzoni AF, Pritts MP (1991). Applications of principal component analysis to horticultural research. HortScience 26(4):334338.

Jacopic J, Slatnar A, Stampar F, Veberic R, Simoncic A (2012). Analysis of selected primary metabolites and phenolic profile of 'Golden Delicious' apples from four production systems. Fruits 67:377-386.

Kaya T, Balta F, Sensoy S (2015). Fruit quality parameters and molecular analysis od apple germplasm resources from Van Basin, Turkey. Turkish Journal of Agriculture and Forestry 39:1-12.

Kecman I (2015). Pomological characterization of apple genotypes from the collection in Srebrenik. MSc Dissertation, University of Banja Luka, Bosnia and Herzegovina.

Kellerhals M, Bertschinger L, Gessler C (2004). Use of genetic resources in apple breeding and for sustainable fruit production. Journal of Fruit and Ornamental Plant Research 12:53-62.

Kevers C, Pincemail J, Tabart J, Defraigne JO, Dommes J (2011). Influence of cultivar, harvest time, storage conditions, and peeling on the antioxidant capacity and phenolic and ascorbic acid contents of apples and pears. Journal of Agricultural and Food Chemistry 59:6165-6171.

Korollaro ML, Endrizzi I, Bertolini A, Aprea E, Dematte ML, Costa F, Biasioli A, Gasperi F (2013). Sensory profiling of apple: methodological apects, cultivar characterisation and postharvest storage. Postharvest Biology and Technology 77:111-120.

Lee KW, Kim YJ, Kim DO, Lee HJ, Lee CY (2003). Major phenolics in apple and their contribution to the total antioxidant capacity.Journal of Agricultural and Food Chemistry 51:6516-6520.

$\mathrm{Lu} \mathrm{R}$ (2004). Multispectral imaging for predicting firmness and soluble solids content of apple fruit. Postharvest Biology and Technology 31:147-157.

Lutaladio NB, Burlingame, Crews J (2010). Horticulture, biodiversity and nutrition. Journal of Food Composition and Analysis 23:481-485.

Milenkovic M (2013). Phenolic composition, antioxidant and antimicrobial activity of parts of the fruit and leaves Prunus spinosa $\mathrm{L}$. from Southeast Serbia. MSc Dissertation, University of Niš, Montenegro.

Miletić R, Žikić M, Mitić N, Nikolić R (2003). Variability of pomological characteristics of the Sumatovka apple. Genetica 35(1):51-58.

Mitić SS, Stojanović BT, Stojković MB, Mitić MN, Pavlović JLj (2013). Total phenolics, flavonoids and antioxidant activity of different apple cultivars. Bulgarian Chemical Communications 45(3):326-331.

Mitre I, Mitre V, Ardelean M, Sestras R, Sestras A (2009). Evaluation of Old Apple Cultivars Grown in Central Transylvania, Romania. Notulae
Botanicae Horti Agrobotanici Cluj-Napoca 37(1):235-237.

Mratinić E, Fortirić Akšić M (2012). Evaluation of phenotypic diversity of apple (Malussp.) Germplasm through the principle component analysis. Genetika43(2):331-340.

Mratinić E, Fortirić Akšić M (2012): Phenotypic diversity of apple (Malu sp.) germplasm in South Serbia. Brazilian Archives of Biology and Technology 55(3):349-358.

Nagasako-Akazome Y, Kanda T, Ohtake Y, Shimasaki H, Kobayashi T (2007). Apple polyphenols influence cholesterol metabolism in healthy subjects with relatively high body mass index. Journal of Oleo Science 56(8):417-428.

Nilsson T, Gustavsson KE (2006). Postharvest physiology of 'Aroma' apples in relation to position on the tree. Postharvest Biology and Technology 43:36-46.

Paunović SA, Paunović AS, Mićić N (1997). Gene centres of wild fruit tree species and their relatives in SFR Yugoslavia. Programme International Horticultural Scientific Conference 'Biological and tehnical development in horticulture', Lednice na Morave, September 9-12th 1997, Appendix II 21-28.

Percival IC (1998). Quantum transfer functions, weak nonlocality and relativity.Physics Letters A 244:495-501.

Peres L, Jackson D, Somers K (2003). Giving meaningful interpretation to ordination axes: assessing loading significance in principal component analysis. Ecology 84(9):2347-2363.

R Core Team (2015). A language and environment for statistical computing. Foundation for Statistical Computing. Vienna, Austria.

Šavikin K, Živković J, Zdunić G, Gođevac D, Đordević B, Dojčinović B, Đordević N (2014). Phenolic and mineral profiles of four Balkan indigenous apple cultivars monitored at two different maturity stages. Journal of Food Composition and Analysis 35(2):101-111.

Selamovska A, Milevska ME, Najdenovska O, Dimovska D (2014). Traditional pear varieties in the west region of Republic of Macedonia. Acta Agriculturae Serbica 19(37):47-60.

Singleton VL, Rosi JA (1965). Colorimetry of total phenolics with phosphomolybdic-phosphotungstic acid reagents. American Journal of Enology and Viticulture 16:144158.

Sneath PHA, Sokal RR (1973). Numerical taxonomy - the principles and practice of numerical classification. Freeman WH and Co., San Francisco.

Tehrani M, Chandran S, SharifHossain ABM, Nasrulhaq-Boyce A (2011). Postharvest physico-chemical and mechanical changes in jumbu air (Syzygium aqueum Alston) fruits. Australian Journal of Crop Science 5:32-38.

Veberič R, Schmitzer V, Petkovšek MM, Štampar F (2010). Impact of shelf life on content of primary and secondary metabolites in apple (Malus domestica Borkh.).Journal of Food Science 75:S461-S468.

Williams WT (1976). Pattern analysis in agricultural science. Elsevier Scientific, New York.

Yuri JA, Neira A, Maldonado F, Quilodrán Á, Simeone D, Razmilic I, Palomo I (2014). Total phenol and quercetin content and antioxidant activity in apples in response to thermal, light stress and to organic management. Journal of Applied Botany and Food Quality 87:131 138. 